PAWEŁ NOWAK*

\title{
OD „KOREANY” DO „ALMA E CORACAO”. SEMANTYKA I PRAGMATYKA PIOSENEK OLIMPIJSKICH
}

Narodziny nowożytnych igrzysk olimpijskich wiązały się z radością, równością, braterstwem, rywalizacją, zabawą i wspólnotowością. W przestrzeni publicznej istnieją różnorodne sposoby wyrażania bycia społecznością olimpijską, przynależności do bardzo licznej grupy ludzi na całym świecie, zjednoczonej ideami, sformułowanymi przez barona Pierre’a de Coubertina. Taki tożsamościowy charakter mają zarówno znicz olimpijski, pięć kółek olimpijskich, flaga olimpijska, jak i wiele pomniejszych znaków graficznych, werbalnych czy dźwiękowych, obecne w symbolicznej przestrzeni publicznej od dziesięcioleci. Jednym z tego rodzaju spajających „olimpijczyków” komunikatów miały być także muzyka, piosenki i hymn olimpijski.

\section{HYMN OLIMPIJSKI WEDEUG PIERRE'A DE COUBERTINA}

Projektując wzorzec ceremonii otwarcia igrzysk olimpijskich, baron Pierre de Coubertin pisał o hymnie olimpijskim w następujący sposób:

Bardziej niz moc dźwięków jest ważny ich rytm. Unikajcie rytmów lekkich, wulgarnych lub po prostu zbytnio zużytych: poważne, powolne sprawia nieskończenie większy efekt. Jeżeli macie trąby miedziane, oddalcie je tak, aby złagodzić ich agresywny rezonans. Jeżeli posiadacie tylko garstkę śpiewaków - przybliżcie ich do widzów. Umieśćcie ich nawet pośrodku trybun, jeśli potrzeba. [...] Jeżeli macie możność wprowadzenia na przemian śpiewu i dźwięków trąbek myśliwskich, odpowiadajacych mu z oddali, nie wahajcie się przed ich wprowadzeniem. ${ }^{1}$

\footnotetext{
* Dr haB. PaweŁ NowaK, prof. KUL - Katedra Języka Mediów i Komunikacji Społecznej Katolickiego Uniwersytetu Lubelskiego Jana Pawła II, e-mail: pawelnowak@kul.lublin.pl.

${ }^{1}$ Pierre de Coubertin, Przemówienia. Pisma różne i listy, red. Grzegorz Młodzikowski i Kajetan Hądzelek, Warszawa 1994, s. 27.
} 
W założeniu twórcy nowożytnych igrzysk olimpijskich muzyka olimpijska miała wzmacniać powagę chwili, podkreślać uroczysty charakter pokojowej rywalizacji narodów, wywoływać u odbiorców katharsis, przygotowywać ich do tego, co będzie się działo na olimpijskich arenach w czasie trwania igrzysk. Nic zatem dziwnego, że hymn olimpijski miał pojawiać się podczas ceremonii otwarcia zawodów i być jednym z centralnych elementów tej uroczystości.

Przez pewien czas baron Pierre de Coubertin myślał o samodzielnym skomponowaniu takiego dzieła muzycznego, ale ostatecznie zamówił ten hymn u Spirosa Samary (muzyka) i Kostisa Palamasa (słowa). Na stadionie w Atenach sportowcy i widzowie usłyszeli zatem patetyczny utwór, zawierający następujące przesłanie:

Nieśmiertelny Duchu Starożytności, Ojcze prawdy, piękna i dobra zstap, ukaż się i opromień swą świattościa nas, tu na tej ziemi i pod niebiosami, które byty świadkami chwaty. Pton w szlachetnych porywach tych Igrzysk: w biegach, zapasach i rzutach: nęć nieosiagalnymi wieńcami i ożywiaj swym płomieniem stalowe pancerze piersi! Skapane w świattości równiny, góry i morza staja się olbrzymia wyzlocona świątynia, do której bieżą wszystkie wielbiace Cię narody, o Duchu Nieśmiertelny Starożytności.

Nic w tym tekście nie zaskakuje. Można nawet powiedzieć, że to idealny przykład hymnu olimpijskiego, ponieważ pojawiają się w nim odesłania do starożytności, do wartości olimpijskich, obecnych od dawna w sporcie (prawda, piękno, dobro), do rywalizacji sportowców (w biegach, zapasach $i$ rzutach). Oś konstrukcyjną kompozycji stanowią bardzo ważne dla ruchu olimpijskiego nawiązania do ducha (Nieśmiertelny Duchu Starożytności) i ognia/światła (opromień swa świattościa, płoń, nęć, ożywiaj swymi płomieniami), które pojawiały się i pojawiają w każdym wystąpieniu i w niemalże każdym symbolu igrzysk.

Decyzja Pierre'a de Coubertina o zatrudnieniu do tworzenia hymnu olimpijskiego w Atenach Greków zapoczątkowała tradycję, która polegała na tym, że uznany muzyk z kraju, w którym odbywały się igrzyska, komponował kolejną wersję hymnu. Było tak także w Paryżu, Saint Louis, Londynie, Sztokholmie, Antwerpii, Amsterdamie oraz Los Angeles.

$\mathrm{Na}$ igrzyska w Berlinie (1936) hymn olimpijski skomponował Ryszard Strauss do tekstu Roberta Lubahna $i$ było to dzieło na tyle wspaniate, że Międzynarodowy Komitet Olimpijski uczynił go oficjalnym hymnem igrzysk. Niestety nie został on odegrany w Londynie, bo uznano go za zbytnio kojarzący się z nazizmem i zagrano oryginalną kompozycję Rogera Quiltera do słów Rudyarda Kiplinga.

Aby zapobiec ciągłym zmianom hymnu, Międzynarodowy Komitet Olimpijski ogłosił w 1954 roku międzynarodowy konkurs, w którym zwyciężyła kompozycja Polaka - Michała Spisaka do tekstu Aleksandra Rymkiewicza na podstawie antycznych „Olimpik” Pindara. Ten „polski” hymn wykonano w 1956 r. w Cortina d'Ampezzo i w Melbourne. I gdy wydawało się, że ostateczna decyzja została podjęta, wdowa po Spirosie Samarze przekazała Międzynarodowemu Komitetowi Olimpijskiemu prawa autorskie do hymnu, skomponowanego na igrzyska w 1896 
r. Komitet podjął zatem decyzję o tym, że to kompozycja Spirosa Samara stanie się jedynym hymnem olimpijskim na kolejne lata. ${ }^{2}$

Zaprezentowana powyżej historia służyła nie tylko pokazaniu dziejów hymnu olimpijskiego ${ }^{3} \mathrm{w}$ XX wieku, ale przede wszystkim podkreśleniu jak ważnym elementem ceremonii olimpijskiej była i jest muzyka, która wraz z ewoluowaniem igrzysk w kierunku komercjalizacji i widowiskowości stawała się jeszcze ważniejsza.

\section{SPEKTAKLE OLIMPIJSKIE - UROCZYSTOŚCI OTWARCIA I ZAMKNIĘCIA IGRZYSK A MUZYKA}

Wśród znawców i miłośników igrzysk olimpijskich funkcjonuje pojęcie ,romantyczne olimpiady"4, „romantyczne mecze"5 itp., dotyczące przede wszystkim czasów międzywojennych oraz lat pięćdziesiątych i sześćdziesiątych XX wieku. Wtedy jedynym ważnym składnikiem zawodów sportowych była sama rywalizacja i jej wynik, pozostałe aspekty miały niezbyt wielkie znaczenie. Mediatyzacja i komercjalizacja sportu oraz wiele innych zjawisk kulturowych w późniejszych latach spowodowały, że ascetyczność i siermiężność rywalizacji sportowej zaczęły ustępować blichtrowi, jarmarczności i efektowności imprezy jako całości, jako spektaklu medialnego ${ }^{6}$.

Igrzyska olimpijskie lat osiemdziesiątych i późniejsze to w równej mierze skupienie się na rywalizacji zawodników, jak i dbałość o oprawę artystyczną, widowiskowość uroczystości otwarcia i zakończenia igrzysk. Z widowiskowością wiązano od zawsze obecność muzyki, dlatego w Moskwie w 1980 r. zabrzmiały fragmenty „Uwertury świątecznej” Dmitrija Szostakowicza, w Los Angeles (1984) i w Atlancie (1996) fanfary olimpijskie, skomponowane przez Johna Williamsa. W innych miastach i państwach olimpijskich było podobnie.?

Jednocześnie kultura nadała zupełnie inną rangę muzyce popularnej. Rewolucja rockandrollowa, związana z Elvisem Presleyem, The Beatles, The Rolling Stones i ich następcami w kolejnych dziesięcioleciach spowodowała, że muzyka popowa, bluesowa, rockowa itp. nabrała wymiaru bardzo masowego. Muzyka wyszła z fil-

${ }^{2}$ Informacje pochodzą z książki Iwony Grys, Muzyka i sport, Warszawa 1998.

3 Maria Rotkiewicz, Dzieje hymnu olimpijskiego, „Sport Wyczynowy” 2008, nr 4-6.

${ }^{4}$ Por. Jan Lis, Romantyczne olimpiady, Warszawa 1984.

5 Por. Bohdan Tomaszewski, Romantyczne mecze, Warszawa 1968.

${ }^{6}$ Joanna Sosnowska, Feeria jako gatunkowy element dramaturgiczny ceremonii otwarcia i zamknięcia igrzysk olimpijskich w mediach, [w:] Elżbieta Pawlak-Hejno, Magdalena Piechota, Paweł Nowak (red.), Igrzyska olimpijskie w mediach masowych: 1948-1984, Wydawnictwo UMCS, Lublin 2016; Media, eros, przemoc. Sport w czasach popkultury, Andrzej Gwóźdź, Kraków 2003.

${ }^{7}$ Hanna Milewska, Muzyka jak chleb dla igrzysk, http://www.hi-fi.com.pl/artyku\%C5\%82y/ muzyka/historie/ 1475-muzyka-jak-chleb-dla-igrzysk (dostęp: 14.03.2017 r.). 
harmonii i klubów na festiwale (to przecież czasy Woodstock - 1969) i na stadiony sportowe (Wembley, Band Aid -1985), a rozgłośnie radiowe i wytwórnie płytowe kreowały masowo kolejne gwiazdy, które sprzedawały dziesiątki milionów płyt i zostawały na scenie przez lata lub znikały po jednym przeboju.

Jednym z miejsc, gdzie to kreowanie lub reklamowanie gwiazd i gwiazdeczek muzyki popularnej przynosiło najlepszy skutek, były i są igrzyska olimpijskie. Za pierwszy przebój muzyki popularnej, wylansowany w symbiozie z odbywającą się wszechświatową imprezą sportową, uważana jest piosenka „Chant Olympique”, skomponowana przez Francisa Lai, a zaśpiewana przez Mireille Mathieu w czasie X Zimowych Igrzysk Olimpijskich w Grenoble w 1968 roku. Jednak dopiero od połowy lat osiemdziesiątych XX wieku piosenki zaczęły być kojarzone z igrzyskami olimpijskimi.

Za początek prawdziwej komercjalizacji igrzysk uważa się Igrzyska Olimpijskie w Los Angeles w 1984 r., ale w wymiarze naprawdę globalnym (nie było wielkich bojkotów) widać ją było w 1988 r. w Calgary i w Seulu. W Calgary rozbrzmiewała Winter game/Can't you feel it, uznanego kompozytora przebojów Davida Fostera, a w Seulu Hand In Hand Koreany, skomponowana przez innego giganta popu i disco Giorgio Morodera. Poza tym z Seulem kojarzono bardzo znaną piosenkę One Moment In Time Whitney Houston.

Kolejne igrzyska przynosiły coraz to nowe pomysły na muzykę olimpijską. W Barcelonie (1992) kompozytorzy postawili na mariaż muzyki rozrywkowej i operowej. Odświeżono Barcelonę Freddie'ego Mercury'ego i Montserrat Cabballe, a oryginalną kompozycją była Amigos para Siempre Sary Brightman i José Carrerasa. W Atlancie (1996) było już wiele piosenek, ale najważniejsze piosenki wykonywały kobiety. Reach zaśpiewała Gloria Estefan, a The Power of the Dream Celine Dion. W Sydney (2000) za utwór związany z igrzyskami uznano wydaną wcześniej bezpretensjonalną, dyskotekową piosenkę Absolutely Everybody Vanessy Amorosi. Z kolei w mormońskim Salt Lake City (2002) utwór promujący igrzyska In My Heart Moby'ego, zagrany na otwarciu, miał wyraźne przesłanie religijne. Konteksty miejsca, w którym rozgrywano igrzyska, czasu, gdy się one odbywały, tradycji oraz narodowe i komercyjne powodowały, że w Atenach (2004) powrócono do źródeł. Czterech najważniejszych muzyków greckich: Trevor Horn, Kotsiras, Tarkan i Yiannis - wykonało utwór Pass The Flame, który przypominał muzykę z pierwszych nowożytnych i nawiązywał do hymnu Spirosa Samary i Kostisa Palamasa z 1896 r. Również druga piosenka, kojarzona z tymi igrzyskami, Oceania islandzkiej piosenkarki Björk była bardzo uroczysta i nastrojowa. Warto wspomnieć także o pierwszej olimpijskiej piosence polskiej ${ }^{8}$. W 2004 r. w radiu i telewizji często można było usłyszeć Jeszcze jeden piękny dzień Andrzeja Smo-

${ }^{8}$ Wcześniej piosenki sportowe w Polsce tworzono i wiązano głównie z mistrzostwami świata w piłce nożnej, a jeśli nawet komponowano utwory na igrzyska, to były one lekceważone lub całkowicie ignorowane przez media i to zarówno te państwowe, jak i te komercyjne. Jedną z przyczyn takiego stanu rzeczy była z pewnością ich nikła wartość artystyczna. 
lika i Artura Rojka. W Vancouver (2010) otwarcie i zamknięcie igrzysk to pokaz gwiazd muzyki popowej i rockowej, a na piosenką igrzysk została namaszczona przez organizatorów One World, One Flame Bryana Adamsa. Z kolei dwa lata wcześniej w Pekinie równie dużo mówiono o startach sportowców, jak i o polityce, a zwłaszcza o dostępie do sieci internetowej, a w zasadzie o jego braku. Piosenka igrzysk You and Me Sary Brightman \& Liu Huana nie zrobiła wielkiej kariery. W Londynie (2012) postanowiono pokazać potęgę Wielkiej Brytanii i bogactwo dawnej korony, a więc wszystko było monumentalne. W tym także sama piosenka igrzysk Survival, którą wykonywała supergrupa Muse. Tą samą drogą podążali organizatorzy w Soczi (2014), a rosyjskie sny o potędze wybrzmiewały w popowym hymnie igrzysk, wykonywanym przez Filippa Kirkorova, Sofię Rotaru, Julię Savichevej, Vladimira Presnyakova, Valeriyę i Dimę Bilana. Ostatnie rozegrane igrzyska w Rio de Janeiro (2016) przez swą geograficzną i kulturową lokalizację zabrzmiały latynoską i popową nutę. Popularna była zatem i oficjalna piosenka Alma e Coração Thiaguinho \& Projota, i dwie ,zachodnie” piosenki: Rise Kate Perry oraz Unstoppable Sia. Należy też pamiętać, że mniej znanych piosenek, w których pretekstem do ich napisania były igrzyska olimpijskie, było co najmniej kilkadziesiąt.

\section{PIOSENKI ILUSTRACYJNE Z TEZĄ CZY SAMODZIELNE, ORYGINALNE TEKSTY? SEMANTYKA PIOSENEK OLIMPIJSKICH}

I w myśli barona Pierre’a de Coubertina, i w myśl założeń czynionych przez organizatorów większości igrzysk olimpijskich centralne w nich miejsce miały i mają zajmować zawody sportowe, rywalizacja między atletami, dążenie do tego, żeby było Citius - Altius - Fortius (szybciej-wyżej-dalej) ${ }^{9}$. Stąd od samego początku nowożytnych igrzysk olimpijskich muzyka obecna na stadionie podczas otwarcia i wokół niego przez czas trwania rywalizacji miała charakter ilustracyjny, a słowa tekstów hymnów olimpijskich, skonstruowane były w oparciu o antyczne toposy i oczywistą symbolikę.

Już w pierwszym hymnie ${ }^{10}$, w którym tekst autorstwa Kostisa Palamasa towarzyszył muzyce Spirosa Samary, pojawił się duch, płomień i różnorodne wartości uznawane za najistotniejsze dla ruchu olimpijskiego - prawda, dobro i piękno. Ten oniryczny i irracjonalny sposób interpretacji idei olimpijskiej powrócił także

${ }^{9}$ Dewiza olimpijska, stworzona przez Henri'ego Didona, a przyjęta jako główne hasło ruchu olimpijskiego przez barona Pierre'a de Coubertaina od 1894 roku.

${ }_{10}$ Jak już wspomniano wcześniej w tym tekście jest to od przełomu lat pięćdziesiątych i sześćdziesiątych XX w. oficjalny hymn igrzysk olimpijskich. 
w piosenkach, przygotowywanych na igrzyska w latach osiemdziesiątych i dziewięćdziesiątych.

Widać w nich sferę sacrum igrzysk, rozumianą nie jako którąś z istniejących religii, ale jako sferę emocji, uczuć, wartości starożytnego i współczesnego humanizmu. Jest zatem Duch Calgary, który otacza, jest w Tobie, czujesz go, jest wszędzie. Ten Duch Starożytności, o którym pisał Kostis Palamas, zastąpiony został duchem miejsca, w którym rozgrywane są zawody, i stało się to normą także w później tworzonych tekstach. Duch Calgary jest dynamiczny i wszechobecny, jest po to, aby wywołać odświętny nastrój w ludziach na całym świecie. Odczuwanie, czucie, mienie go w sobie, przė̇ywanie silnych emocji, związane z igrzyskami olimpijskimi, także stały się motywem obecnym w większości piosenek olimpijskich.

Świat wewnętrzny oprócz uczuć, emocji, nastroju uzupetnia sen, który jest doskonaty albo czyni rzeczywistość jest, podobnie jak poprzednie składniki piosenkowego świata wewnętrznego, bardzo dynamiczny ${ }^{11}$. W różnych tekstach pojawiają się zatem frazy: Ten sen otulit mnie ciepło; $W$ tym sennym marzeniu byliśmy ty i ja; Chcę, by caty świat zobaczyt teraz mój sen; Sen powoli staje się jawa; Ten sen będzie mój; Siła snu; Spetnione sny.

Oprócz ducha/uczuć i snów w tej różnorodnej triadzie nie może także zabraknąć marzeń: ujawnią się nasze nadzieje i marzenia; Niektóre marzenia trwają wiecznie, Marzenia, których pragnę z catego serca; Aby zblizyło nas do mocy marzenia. Jednak marzenia nie są już tak dynamiczne, są tylko ekstremalne, najgłębsze, pełne siły, bo marzenia mają się spełnić, więc ich tekstowy obraz jest oparty na standardowych, zwyczajnych, potocznych konotacjach i skojarzeniach.

Jest zatem w tych piosenkach silny duch, który gwarantuje także siłę ciała, moc cielesności, sprawność uczestników zawodów, bo idea kalos kagathos (piękny $i$ dobry) to także jedna $\mathrm{z}$ tych, na których opiera się współczesny ruch olimpijski.

Człowiek olimpiady (człowiek-olimpijczyk i człowiek-kibic) zbudowany jest typowo, ale tylko niektóre części ciała zyskały uznanie w oczach autorów tekstów piosenek. Oczywiście, ze względu na wieloraką symbolikę i wyrazistość gestu najczęściej w analizowanym materiale pojawiają się ręce (trzymamy się za ręce; podnosimy ręce; Każdy potrzebuje ręki do trzymania). Z reguły są to konteksty, w których zachowanie rąk symbolizuje jedność i braterstwo, oznacza entuzjazm, wskazuje na bliskość i uczuciowość, czyli ma standardowy kontekst językowy i interpretację rzeczywistości też ma standardową, potoczną, akceptowalną przez język ogólny.

A skoro o uczuciowości i bliskości mowa to drugą częścią ciała na mapie cielesności człowieka w tekstach piosenek olimpijskich jest serce (Eamałam swe

${ }^{11}$ Właśnie dynamika uczuć czy snów w piosenkach okołoolimpijskich jest najbardziej niestandardowym elementem tych tekstów. Sen ani uczucie nie bywają tu zbyt często głębokie, ale są zawsze w ruchu, przenikaja lub wnikaja w człowieka. Oczywiście, wynika to z istoty rywalizacji sportowej i wartości wyznawanych przez ruch olimpijski, nie mniej jest ciekawym rozszerzeniem konotacji obu wyrazów i innych z pola semantycznego nazw elementów świata wewnętrznego. 
serce; Gdy każdy z mych snów, jest o jedno uderzenie serca ode mnie; robi mi się cieplej na sercu; pragne z catego serca; szczere serca, „Dusza i serce”; W moim sercu chcę). Nie ma w tych fragmentach zbyt wiele oryginalności, tym bardziej, że część z tych utworów jest tak naprawdę o miłości i zostało jedynie dopasowane do olimpijskiego kontekstu. Zatem serce uderza i z miłości, i z wysiłku na zawodach, bo chce za wszelką cenę zwyciężyć (pragna z catego serca), robi się cieplej na sercu człowiekowi-kibicowi, gdy widzi tych młodych ludzi, rywalizujących w szlachetnym współzawodnictwie, bo wszyscy ludzie-olimpiady mają szczere serca. A ponieważ szczerość serca widać także w oczach (oczywiście, w standardowym, nienaukowym obrazie świata), więc bohaterowie większości piosenek utrzymują kontakt wzrokowy: potrafisz spojrzeć w moje oczy; oczy mi się śmieja.

$\mathrm{Z}$ tego ponownie jak najbardziej naturalnego, typowego i potocznego połączenia ducha i ciała, harmonii panującej między nimi rodzi się jeszcze jeden obraz procesów i relacji cielesnych, wynikających z bliskości uczuciowej i duchowej: Każdy potrzebuje kogoś do kogo może przylgnąć; Każdy potrzebuje ludzkiego dotyku albo będących wynikiem rywalizacji na arenach olimpijskich: Każdy oddycha i każdy krwawi; krew krąży szybciej; zwycięstwo płynie w moich/twoich żyłach.

Interesujące są zwłaszcza ostatnie konteksty obrazujące wysiłek zawodników. Człowiek staje się w nich pneumą, limfą, ciało sportowca zamienia się w wysiłek, a krew w wolę zwycięstwa. I o ile w poprzednich kontekstach była mowa o każdym (mnie, tobie i wszystkich innych), a wielki kwantyfikator miał podkreślić wspólnotowość i organiczność społeczności olimpijskiej (a w tym wypadku zapewne całego świata) to walka na bieżni czy innym olimpijskim obiekcie jest tylko i aż mojaltwoja.

W związku z tym w tych piosenkach wszystko się czuje - nie istnieje zwyczajność, obojętność, neutralność.

Czuję, że żyje, ale głównie czuje ducha, uczucie i przede wszystkim płomień, zwłaszcza ten, który płonie w sercu, poczuj płomień, który ciagle płonie, ale także przy sobie, ma go w oczach:

Czujemy płomień wiecznie płonacy w nas; Podnieśmy ręce do nieba; Poranny spokój pomaga nam żyć w harmonii; Przez cały czas; Podaj płomień. A zatem interpretacja rzeczywistości w tekstach utworów okołoolimpijskich zatoczyła koło, bo w pierwszym hymnie olimpijskim też były i duch, i płomień, i dużo uczuć. Poza tym podmioty w piosenkach pragna, marza (wymarzaja) i wierza, doświadczaja bólu czy czuja słodycz.

Trudno zatem nie zauważyć, że znaczenia tekstów piosenek olimpijskich to niewątpliwie semantyka emocji, z każdymi kolejnymi igrzyskami coraz mniej związana z tymi zawodami, a raczej wykorzystująca marketingową okazję, aby wypromować swój singiel lub płytę (nierzadko skomponowany wcześniej). Stąd wiele z nich może być po prostu interpretowana, jak podobno każda piosenka, jako opowieść o miłości, jej braku, poszukiwaniu lub szczęściu. Nie da się nie zauważyć, że w pogoni za popularnością i liczbą wyświetleń na YouTube semantyka tekstów 
tych piosenek ewoluuje coraz bardziej w kierunku coachingu życiowego, a zawarte w nich przesłanie można byłoby opisać jako: 'walczysz/grasz, jesteś silny, marzysz i spełniasz marzenia, wygrywasz, dasz radę, nie wolno Ci wątpić i się poddawać'.

\section{PRAGMATYKA TEKSTÓW PIOSENEK OLIMPIJSKICH}

Skoro semantycznie teksty tych piosenek to coraz częściej przekazy, przypominające mowy motywacyjne z coachingu życiowego, także ich pragmatyka musi mieć odpowiedni charakter - motywacyjny/ nakazowo-zakazowy.

Większość zdań padających w tych tekstach to mikroakty mowy dyrektywne i ekspresywne, obudowane komisywami.

W tych piosenkowych dyrektywach pojawiają się formy drugiej osoby liczby pojedynczej, np. spróbuj, zobacz, poczuj, wzmacniając w ten sposób zaangażowanie odbiorcy w słyszany przekaz, podkreślając troskę o odbiorcę i odczuwaną przez nadawcę bliskość i równość komunikacyjną.

Zaangażowanie i przeżywanie potwierdzają także ekspresywy, w których forma ty ustępuję pola formie my oraz w mniejszym stopniu $j a$. W większości tekstów czujemy, cieszymy się, podziwiamy, kochamy, walczymy. Znane już w retoryce i erystyce starożytnej my wspólnotowe, tzw. my inkluzywne, z łatwością przekonuje, że dyrektywność tych przekazów istnieje zarówno w warstwie jawnej (lokucji), jak i w warstwie ukrytej (perlokucji). Aby te, z piosenkowej konieczności dość proste, zabiegi perswazyjne przyniosły zamierzony efekt warto je wzmocnić, używając częściej ukrytych niż jawnych komisyw (zwanych także zobowiazaniowcami). Nie padają raczej w tych tekstach czasowniki performatywne: obiecuję, przyrzekam, przysiegam, gwarantuję czy daję słowo, natomiast różne frazy w nich użyte mogą być tak interpretowane. Wiele $\mathrm{z}$ tych wypowiedzi to po prostu „performatywne asercje”, w których opowieści o igrzyskach są przesycone dodatkowymi intencjami i skutkami.

Analizowane teksty nie są gęste semantycznie i pragmatycznie, ale ze względu na różnorodność aktywowanych przez nie kontekstów i ram interpretacyjnych oraz zamierzonej niedookreśloności tematyki ${ }^{12}$ dominuje w nich komunikacja nie wprost, kooperacja presupozycji i implikatur.

$* * *$

${ }_{12}$ Wielokrotnie było już to podkreślane, że wiele $\mathrm{z}$ tych piosenek miało mieć bardzo różne przeznaczenie, np. być piosenką olimpijską i przebojem lata albo znaleźć się później w ścieżce filmowej obrazu o sporcie. 
Pomimo że piosenki olimpijskie pojawiały się już wcześniej to na dobre zadomowiły się w świecie zawodów olimpijskich na igrzyskach 1988 roku - w Calgary i w Seulu. I choć na obu tych imprezach piosenki były oryginalne, to identyfikowany jako związany z igrzyskami w Seulu przebój Withney Huston pochodził z płyty, na której znalazło się kilka piosenek o miłości jako sporcie z 1987 r.

Także w Barcelonie wykorzystano piosenkę nagraną 4 lata wcześniej i popularnością pokonała ona piosenkę przygotowaną specjalnie na igrzyska. Potem bywało już różnie, nie tylko $\mathrm{z}$ oryginalnością piosenki, ale także $\mathrm{z}$ jej sensem i często bardzo luźnym związkiem z igrzyskami i rywalizacją sportową.

$\mathrm{W}$ ostatnich latach uroczystości otwarcia i zamknięcia igrzysk to często specyficzne koncerty muzyki rozrywkowej z wieloma wykonawcami i piosenkami, które później, przynajmniej w założeniach, mają się kojarzyć słuchaczom z tymi zawodami.

Kwintesencję „kryzysu” piosenki olimpijskiej pokazuje ten refren:

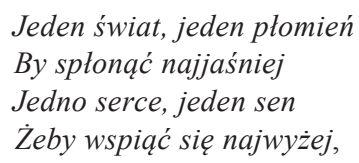

w którym powielane są w większości motywy i kolokacje znane z wcześniejszych analiz. Nie jest to jednak piosenka ani z lat osiemdziesiątych, ani z dziewięćdziesiątych XX wieku. To utwór Bryana Adamsa „One World, One Flame” z Vancouver z 2010 roku, a tak naprawdę pasowałby do każdych igrzysk olimpijskich.

\section{BIBLIOGRAFIA}

Pierre de Coubertin, Przemówienia. Pisma różne i listy, red. Grzegorz Młodzikowski i Kajetan Hądzelek, Warszawa 1994.

Iwony Grys, Muzyka i sport, Warszawa 1998.

Jan Lis, Romantyczne olimpiady, Warszawa 1984.

Hanna Milewska, Muzyka jak chleb dla igrzysk, http://www.hi-fi.com.pl/artyku\%C5\%82y/muzyka/ historie/ 1475-muzyka-jak-chleb-dla-igrzysk (dostęp: 14.03.2017 r.).

Maria Rotkiewicz, Dzieje hymnu olimpijskiego, „Sport Wyczynowy” 2008, nr 4-6.

Media, eros, przemoc. Sport w czasach popkultury, red. Andrzej Gwóźdź, Kraków 2003.

Bohdan Tomaszewski, Romantyczne mecze, Warszawa 1968.

Joanna Sosnowska, Feeria jako gatunkowy element dramaturgiczny ceremonii otwarcia i zamknięcia igrzysk olimpijskich w mediach, [w:] red. Elżbieta Pawlak-Hejno, Magdalena Piechota, Paweł Nowak (red.), Igrzyska olimpijskie w mediach masowych: 1948-1984, Lublin 2016. 


\section{Streszczenie}

W przestrzeni publicznej istnieją różnorodne sposoby wyrażania bycia społecznością olimpijską, zjednoczonej ideami barona Pierre'a de Coubertina. Taki charakter mają znicz olimpijski, pięć kółek olimpijskich, flaga olimpijska i wiele znaków graficznych, werbalnych i dźwiękowych, obecnych w symbolicznej przestrzeni publicznej. Jednym z tego rodzaju spajających „olimpijczyków” komunikatów miały być także muzyka, piosenki i hymn olimpijski.

Kilkadziesiąt piosenek, które przez ostatnie 30 lat były kojarzone z igrzyskami opiera się na semantyce emocji i interpretacji ducha, płomienia, snu, marzeń, które w zależności od autora tekstu mają bardziej lub tylko nieco mniej sztampowy charakter. Nie są zbyt gęste semantycznie i pragmatycznie, ale aktywują różne konteksty i ramy interpretacyjne oraz są niedookreślone tematycznie (nie wiadomo często, czy są o sporcie czy o miłości). Z pewnością jest w nich komunikacja nie wprost, a kooperacja opiera się na presupozycjach i implikaturach.

Słowa-kluczowe: Piosenka olimpijska, semantyka, pragmalingwistyka, kontekst, rama interpretacyjna, presupozycje, konotacje, implikatury

\section{FROM „KOREANA” TO „ALMA E CORACAO”. \\ SEMANTICS AND PRAGMATICS OF OLIMPIC THEME SONGS}

\section{Sum mary}

In public space there is a variety of means to express the feeling of belonging to the Olympic community united by the ideas of Baron Pierre de Coubertin. The Olympic torch, five Olympic circles and the Olympic flag all represent this, so do many graphic, verbal and sound signs present in the symbolic public space. One of such messages uniting 'the Olympians' would be music, Olympic songs and the Olympic anthem.

The several dozens of songs associated with the Olympic games throughout last 30 years are based on the semantics of emotion and the interpretation of spirit, flame, dream which, depending on the author, are more or less clichéd. They are not overly substantial in semantic and pragmatic aspect, but they do activate different contexts and interpretational frames; they are also vague in terms of the theme (it is often unclear whether they are about sports or love). Surely the communication in them is not direct and cooperation is based on presuppositions and implications.

Keywords: Olympic theme songs; Semantics, Pragmalinguistics, Context, Interpretation frame; Presupposition; Connotations; Implications 